DOI 10.15393/j9.art.2018.5261

УДК 821.9+008

\author{
Наталья Николаевна Бедина \\ (Архангельск, Российская Федерация) \\ bedina-nat@yandex.ru \\ Ольга Сергеевна Ившина \\ (Архангельск, Российская Федерачия) \\ olgaivs1994@mail.ru
}

\title{
Мифопоэтические и христианские мотивы в трилогии о Яёвеншёльдах С. Лагерлёф
}

Аннотация. Особенностью художественной концепции С. Лагерлёф является сосуществование в рамках одного текста мифологической, фольклорной и христианской традиций, вымысла и реальности, мистики и психологизма. Цель данного исследования - проследить особенности взаимодействия фольклорной и христианской традиций в трилогии о Лёвеншёльдах, используя мотивный анализ. Первая часть трилогии («Перстень Лёвеншёльдов») ориентируется на жанры фольклорного демонического рассказа и одновременно - готического романа конца XVIII в.; вторая часть («Шарлотта Лёвеншёльд») соответствует свадебной обрядовой традиции и в то же время реализует жанрово-стилистические особенности романтического психологического романа первой половины XIX века; третья часть («Анна Сверд») преобразует сказочную фольклорную традицию в неоромантический роман второй половины XIX - начала XX в., учитывающий литературный опыт реалистического романа. С. Лагерлёф проводит читателя через всю историю шведской (шире - европейской) культуры и одновременно по пути христианского преображения: от подчинения человеческим страстям в первой части, через самопожертвование и любовь во второй, к приятию мира и смирению в третьей.

Ключевые слова: С. Лагерлёф, неоромантизм, трилогия о Лёвеншёльдах, фольклорные мотивы, христианская идея, преображение

Ш

ведская писательница Сельма Лагерлёф (Selma Ottilia Lovisa Lagerlöf, 1858-1940) стала первой женщиной, удостоенной Нобелевской премии по литературе. Она была вручена ей в 1909 г. за «дань высокому идеализму, яркому воображению и духовному проникновению, которые отличают все ее произведения» ${ }^{1}$ Развиваясь в русле и под влиянием скандинавской в целом и шведской литературы в частности, С. Лагерлёф стала ярким представителем европейской неоромантической

(c) Н. Н. Бедина, О. С. Ившина, 2018 
традиции [Кобленкова, 2012, 2017]. Отдав литературе пятьдесят лет, она создала более двадцати произведений, поставивших ее имя в ряд крупнейших писателей современности.

Трилогия о Лёвеншёльдах (Lowenskoldska ringen) является последним крупным сочинением C. Лагерлёф (исключая автобиографические тексты), итогом литературного опыта писательницы. По мнению шведского литературоведа, профессора Джона Ландквиста (John Landquist), во второй части трилогии, названной «Шарлотта Лёвеншёльд», С. Лагерлёф достигла «высоты настоящего гения», а третья часть - «Анна Сверд» - всегда будет занимать выдающееся место в творчестве писательницы, так как в ней С. Лагерлёф продемонстрировала глубокое и всеобъемлющее знание людей [Landquist].

Цель настоящей статьи - выявить в сюжете трилогии систему мифологических и фольклорных мотивов и показать их трансформацию в литературном тексте в соответствии с христианской идеей преображения. Как пишет Е. А. Гаричева (Федорова), феномен религиозного преображения предполагает, что «в сознании <человека> одновременно существуют два образа: свой, несовершенный, греховный, и совершенный Образ Божий как цель, которую необходимо достигнуть. Таким образом, феномен религиозного преображения выражает категорию самосознания личности, но он также определяет и особенности поэтики литературного произведения» [Гаричева: 11]. Не без влияния русской классической литературы XIX века поэтика, жанровая природа и мотивная структура трилогии о Лёвеншёльдах С. Лагерлёф определена этой идеей.

Вслед за В. Е. Хализевым под мотивом мы понимаем устойчивую семантическую единицу, присутствующую в тексте в самых разных формах: мотив «может представлять собой отдельное слово или словосочетание, повторяемое и варьируемое, или представать как нечто обозначаемое посредством различных лексических единиц, или выступать в виде заглавия либо эпиграфа, или оставаться лишь угадываемым, ушедшим в подтекст. Сферу мотивов составляют звенья произведения, отмеченные внутренним, невидимым курсивом...» [Хализев: 280]. Мотивный анализ текста трилогии позволяет показать, 
как, используя традиционные мотивы фольклорных и литературных жанров, С. Лагерлёф реализует идею пути героя от подчинения человеческим страстям в первой части, через самопожертвование и любовь во второй, к приятию мира и смирению в третьей.

Действие трилогии разворачивается на фоне исторических событий Швеции начала XVIII - середины XIX века. В ней рассказывается запутанная история старинного рода Лёвеншёльдов. Мифологический и фольклорный контекст трилогии составляют в первую очередь скандинавская мифология, исландские саги, героические песни «Старшей Эдды», народные легенды и семейные предания (см. об этом подробнее: [Плахтиенко]), а также универсальные мифологические и фольклорные мотивы, искусно трансформированные, интерпретированные и вплетенные в канву произведения, отвечающего духу неоромантической литературной традиции.

Первая часть из трилогии о Лёвеншёльдах — «Перстень Лёвеншёльдов» - ориентируется на фольклорный жанр демонического рассказа и реализует характерную для него систему мотивов. В основе сюжета - кража из семейного склепа перстня, принадлежавшего прославленному покойному генералу Бенгту Лёвеншёльду. Каждого, кто становится обладателем этого перстня, настигает несчастье и преследует призрак генерала. Лишь только после возвращения перстня обратно, в могилу его настоящего владельца, призрак обретает покой.

Одним из основных фольклорных мотивов первой части трилогии становится мотив проклятого золота, приносящего несчастья всем, кто им владеет. Золотой перстень был пожалован генералу Бенгту Лёвеншёльду самим Карлом XII за преданность и верность королю. Этот перстень был столь же знаменит и прославлен, как и сам генерал, поэтому его владельца похоронили вместе с перстнем.

Мотив золота, приносящего несчастья его владельцам, «известен фольклору самых разных народов» [Криничная, 1977]. Это один из самых архаических мотивов героического эпоса германского народа. Он встречается и в англосаксонском эпосе «Беовульф», где древние сокровища приводят героя 
к гибели, и в немецком эпосе «Песнь о Нибелунгах», и в эддической поэзии (см. об этом: [Гуревич, 1979]). По мнению Е. М. Мелетинского, мотив проклятого золота переплетается не только с древнескандинавской идеей судьбы, но может служить и метафорой сил, разъедающих патриархальное общество в «эпоху викингов» [Мелетинский, 1984: 476].

Разъедающая сила золота трактуется С. Лагерлёф как нравственная проблема. Перед кражей перстня в первой части трилогии крестьянин Борд Бордссон и его жена сначала объясняют себе желание увидеть открытый склеп с могилой генерала добрыми намерениями защитить ее от воров. Затем автор указывает на некую мистическую силу, которую крестьяне не осмеливаются назвать:

«Растерянные и нерешительные, стояли они, уставившись на черный, зияющий пролом. Им бы пойти теперь домой, но нечто таинственное, нечто такое, чего никто из них не осмелился назвать своим именем, удерживало их на кладбище»².

Далее автор сталкивает две точки зрения на действия героев - желаемую и действительную:

«- Он ведь, поди, не думает, что мы замыслили отнять у него, что ему всего дороже, - молвила жена. - Вот кабы мы крышку гроба подняли, тогда другое дело.

— Да, ну тут уж придется тебе мне пособить, — сказал муж» (15).

И наконец, прямо произносится имя таинственной силы, приведшей крестьян к могиле генерала: «Они подняли крышку и теперь уже не в силах были сдержать алчность» (15). Алчность разъедает душу и сына Бордссонов Ингильберта, который, несмотря на все бедствия, постигшие родителей, готов на убийство ради золотого перстня.

Образ генерала («Бенгта-силача») и образ Карла XII представлены С. Лагерлёф как образы эпических национальных героев и одновременно как варианты мифологических предков (генерал является непосредственным прародителем Лёвеншёльдов): их уважают, любят и боятся, про них слагаются истории, им приписывается недюжинная сила и власть над живущими людьми. 
Генерал Бенгт надеялся на то, что после его смерти он будет рядом с королем: перстень станет опознавательным знаком для Карла XII в загробном мире, и тот примет его в свой сонм вместе с другими воинами. В скандинавской мифологии есть подобное представление о вечном обновлении жизни в Вальхалле - своего рода «рае» для погибших доблестных воинов (см. об этом: [Мелетинский. Вальхалла]). В архаической культуре сакраментальная значимость металлов проявлялась в том, что они служили отличительным знаком социального статуса, авторитета и доблести. Украшения из драгоценных металлов выставлялись напоказ. Дружинники добивались от своих вождей подарков (колец и т. п.), так как считалось, что вместе с даром воин получал и заключенную в нем частицу «удачи» вождя, его магической силы и счастья, обладателем которых он являлся. Таким образом, получая драгоценные дары, приближенные приобщались к сущности вождя. Лишение их означало гибель, утрату боевой удачи.

В эпоху средневековья золото «не имело широкого применения в товарно-денежных отношениях. Сокровища <...> обладали сакраментальной силой, в них материализовались счастье и успех их обладателей. Вот почему богатства запрятывались навсегда так, чтобы никто не мог ими воспользоваться, иначе их владелец мог лишиться не только магической силы и поддержки, но даже жизни». Запрятывание клада сопровождалось обрядом, включавшим заговор и жертвоприношение, благодаря чему клад обретал душу и телесное воплощение [Криничная, 1977], (см. также: [Гуревич, 1984]). К примеру, у норманнов был распространен обычай, находящий отражение в исландских сагах, прятать захваченные сокровища, не предполагая последующего их изъятия: «...клад, пока он лежал нетронутым в земле или на дне болота, хранил в себе удачу своего хозяина и поэтому был неотчуждаем» [Гуревич, 1984: 198]. Согласно В. К. Соколовой, изучавшей эту традицию в славянском фольклоре, «истоки поверий о кладах коренятся в древних народных верованиях, в представлениях о богатствах, скрытых в недрах земли, которые в свое время откроются; о духах, “хозяевах” их, хранителях сокровищ» [Coколова: 188]. По североевропейским преданиям, скрытое 
богатство защищено сверхъестественным существом, которое считается призраком первоначального владельца или призраком животного, принесенного в жертву. В «сагах о древних временах» часто встречается сюжет о добывании клада из кургана, состоящий из одних и тех же повторяющихся мотивов, в том числе включающих схватку с могильным жителем, охраняющим сокровища (см.: [Стеблин-Каменский, 1976: 157-158]).

Безусловно, образ призрака генерала Бенгта Лёвеншёльда, преследующего всех, у кого оказывается его перстень, несет на себе черты фольклорного «хранителя» и хозяина клада и одновременно восходит к общим, универсальным представлениям о демоническом существе как душе умершего предка, затерявшейся между миром жизни и миром смерти (см.: [Левкиевская: 263]). Призрак генерала у С. Лагерлёф описывается как «свирепый и беспощадный», не отступающий до тех пор, пока не разрешится конфликт, связанный с потревоженной могилой и кражей перстня.

Как отметила М. Сеттервол (Setterwall), неупокоенность души чаще всего связана с незавершенным делом между мертвыми и живыми, неискупленным грехом за преступление или неправильно соблюденным похоронным обрядом (см. об этом: [Setterwall]). В славянской демонологии мотив неупокоенности души соотносится с представлением о «заложных» покойниках (людях, умерших неестественной или преждевременной смертью, души которых бродят по земле) (см.: [Виноградова: 49-53], [Толстой: 538]). Л. Н. Виноградова пишет о том, что умерший становится демоническим существом, если у него остались окончательно не разорванные связи с живыми: «...не исполненное близкими людьми желание умирающего, неулаженная ссора, невозвращенный долг, сильная эмоциональная привязанность к членам семьи, чувство мести или обделенности» [Виноградова: 43].

В демоническом рассказе актуальным является мотив фронтира. Граница между своим и чужим мирами является определяющим фактором, поскольку «только при восприятии сверхъестественного как реальности, как достоверного факта» становится возможным тесное взаимодействие между мирами [Померанцева: 21]. «Свое» соотносится с освоенным человеком пространством, принадлежащим ему; «чужое» - с нечелове- 
ческим пространством, хаотичным, звериным или, наоборот, божественным. Граница - пространственный рубеж, разделяющий их (см. об этом: [Байбурин: 183-194], [Толстой: 537-540], [Элиаде: 113]). Существуют как естественные границы - лес, река, дорога, так и созданные человеком - окна, двери, порог, ворота и т. п.

В «Перстне Лёвеншёльдов» «пограничное» пространство непосредственно связано с появлением призрака генерала Лёвеншёльда. Одним из таких пространств в первой части трилогии выступает дремучий лес - бор, «напоминающий звериную шкуру». Дочь Борда Бордссона, узнав о похищении перстня отцом, в испуге видит, что «генерал стоит под елками» (21). Задумав отобрать перстень у пастора, сын Бордссона Ингильберт проводит священника через лес, а в лесу ведет его гатью через болото; пастор замечает, как сын крестьянина, «потемнев лицом, стиснув зубы, одолевает коня, чтобы столкнуть его вниз в вязкую топь. И животное и всадника ждала верная смерть» (26). В лесу же ротмистр, сын генерала, со своими людьми обнаруживают трех крестьян, несущих на носилках уже покойного Ингильберта Бордссона, принявшего смерть от страха перед призраком. В этот момент все ощущают присутствие генерала рядом с носилками: «Он вышел из лесу вместе с мертвецом. Он стоял, указывая на него пальцем» (34).

В этом «пограничном» пространстве (лесу, боре и т. п.) с людьми происходят внешние и внутрение изменения. Как только ротмистр и его люди зашли в лес, их словно подменили: они обрели совсем иной вид, иную осанку - их обуял охотничий пыл. Жажда мести как звериное начало с неодолимой силой просыпается в ротмистре Лёвеншёльде именно в пространстве леса, так же, как и жажда золота овладевает Бордссонами в пространстве кладбища.

Если проследить, в каких частях дома (усадьбы) появляется призрак генерала, то можно заметить, что это происходит в основном в «пограничных» местах: чердак, сени, лестница, дверной проем. Когда С. Лагерлёф описывает явление призрака Адриану Лёвеншёльду, она неоднократно повторяет слово «порог», через который необходимо переступить юноше, чтобы следовать за генералом. Этот путь Адриана, в детской шапочке 
которого спрятан перстень, приводит его на край гибели, что соответствует фольклорной логике контакта с демоническими существами - представителями иномирия. Спасти Адриана от смерти способна только любящая его Мальвина Спаак, дочь бедного пастора, ставшая домоправительницей в усадьбе Лёвеншёльдов. Можно предположить, что с универсальной оппозицией «свой / чужой» связан и выбор генерала себе в «помощницы» не принадлежащей к роду Лёвеншёльдов Мальвины Спаак, на которую поэтому не распространяется гнев генерала и которая так же, как и он, «чужая» в пространстве усадьбы. В конце концов именно Мальвина Спаак находит перстень и возвращает его в склеп генерала Лёвеншёльда.

Мифологема «свой / чужой» - оппозиция, характерная для архаического сознания, - проявляется в трилогии в дихотомии между севером и югом, а также в настороженном отношении персонажей к «чужакам».

Одним из ключевых эпизодов первой части трилогии является «Божий суд», когда ротмистр Лёвеншёльд обвинил в краже перстня троих уважаемых крестьян, нашедших в лесу погибшего Ингильберта Бордссона. Крестьяне были преданы суду и впоследствии несправедливо казнены. Одна из причин их обвинения состояла в том, что Пауль Элиассон, младший из трех крестьян, «по рождению иноземец, а об иноземцах известно, что кражу они не считают за грех» (42). В ходе расследования решение было передано в руки «Божьего суда» (известный мотив в поздней эддической поэзии [СтеблинКаменский, 1984: 82-104]): все трое по очереди должны выкинуть игральные кости на тинге (народном собрании); у кого выпадет наименьшее количество очков - тот и виновен. Каждый выкинул по максимальному количеству очков, и королевский суд постановил, что виновны все трое. Решение суда местными жителями было расценено как величайшая несправедливость: «Говорили, что быть, мол, приходу Бру разоренным, как Иерусалиму, потому что там лишили жизни трех безвинных мужей» (55).

С одной стороны, здесь реализуется мифопоэтический мотив судьбы, также актуальный для жанра демонического рассказа (см. об этом: [Danielson]). Однако в текстах С. Лагерлёф всегда 
существует несколько пластов прочтения: одно и то же событие может быть осмыслено с разных точек зрения, одинаково возможны две его трактовки - влияние некой силы, имеющей мистическую власть над человеком (фольклорная традиция), и сознательный нравственный или безнравственный выбор человека, за который он несет личную ответственность (христианская трактовка). В эпизоде «Божьего суда» С. Лагерлёф дает возможность этической интерпретации:

«Множество проклятий призывалось на голову ротмистра Лёвеншёльда. Говорили, будто он побывал в Стокгольме и по его вине приговор Божьего суда истолковали в ущерб обвиняемым» (55).

В конечном итоге текст первой части трилогии, сюжет которой построен по законам фольклорного демонического рассказа, приобретает абсолютно иной смысл благодаря финальному описанию призрака генерала:

«Как и ожидал Адриан, то было лицо старика. Он хорошо знал его по портрету в гостиной. Но черты этого лица не излучали вечного покоя, в чертах его проглядывала яростная алчность, а на устах призрака играла зловещая улыбка торжества и уверенности в победе.

Как ужасно было видеть, что земные страсти обуревают мертвеца! Покойных мы хотим представлять себе пребывающими вдали, далекими от всех человеческих наслаждений и страстей. Отрешенными от всего мирского хотим мы видеть их, преисполненными лишь помыслов небесных. В этом же существе, которое оставалось приверженным ко всему земному, ему почудился искуситель, злой дух, который хочет навлечь на него погибель» (71).

Не идея высшей справедливости, не неотвратимость наказания за совершенное преступление, а человеческие страсти движут генералом - алчность, тщеславие, гордыня. Выбор, совершающийся в душе человека, - вот основа художественного мира С. Лагерлёф. Не случайно повествование о «Божьем суде» непосредственно предваряет аллегорическое сравнение пламени домашнего очага и человеческой души:

«...ибо что такое человеческая душа, как не резвящееся пламя? Да, да, она и есть огонь! Она вспыхивает в самом человеке, 
охватывает его и кружится над ним, точь-в-точь как огонь вспыхивает в серых поленьях, охватывает их и кружится над ними» (39).

Победить «злую силу» человеческих страстей в мире С. Лагерлёф способна только любовь. Марит Эриксдоттер, невеста Пауля Элиассона, потерявшая в результате «Божьего суда» отца, дядю и возлюбленного, была единственной на площади, кто любящим сердцем сочувствовал обвиняемым и верил в их невиновность от начала и до конца. Через много лет она обнаруживает шапочку, которую Пауль, видимо, подобрал за умершим Ингильбертом Бордссоном, а в ней - зашитый перстень Лёвеншёльдов. Марит, мучаясь несправедливостью суда и жаждой мести ротмистру, находит случай перевести гнев генерала Лёвеншёльда на его же потомков: когда ее попросили починить шапочку Адриана, правнука генерала, она перепрятывает туда перстень. Но много позже, увидев душевную боль любящей Адриана Мальвины Спаак, Марит преодолевает в себе желание отомстить за «великую неправду», которую вынесли ее родные, и помогает Мальвине найти перстень, чтобы вернуть его призраку. Таким образом, христианская идея любви, возвышающейся над справедливостью и побеждающей смерть, преобразует мотивную систему демонического рассказа и переводит ее в литературно-эстетическую реальность.

С. Лагерлёф вводит в первую часть трилогии элементы готического романа XVIII века, обязательными мотивами которого становятся явление призрака, семейные тайны, испытание влюбленных и т. д. «Готическая» проза XVIII в. сочетает в себе сверхъестественный фантастический сюжет с ужасной и таинственной атмосферой, с «готическими» злодеями и чудесными происшествиями (см., напр.: [Напцок: 141]). В логике этой традиции разворачивается и мотив проклятого рода, проходящий затем через все части трилогии. С точки зрения сюжетного строения этот мотив берет начало в финале «Перстня Лёвеншёльдов»: Марит Эриксдоттер соглашается помочь спасти Адриана только при условии, что Мальвина Спаак и Адриан Лёвеншёльд поженятся, но данное матерью Адриана слово не исполняется - он уже помолвлен с другой. Марит произносит роковые слова: 
«Трое моих претерпели насильственную смерть! <...> Трое твоих тоже примут лютую скоропостижную смерть, потому как ты не держишь слово!» (515).

Мотив проклятого рода имеет мифологические корни. А. Ф. Лосев замечает, что мифы о родовом проклятии присущи эпохе разложения героической мифологии и рассказывают о гибели нескольких поколений подряд [Лосев: 96]. Важность этого мотива прослеживается на протяжении всей трилогии.

Сюжетной основой второй и третьей частей трилогии являются истории Шарлотты и Карла-Артура Лёвеншёльдов.

Вторая часть - «Шарлотта Лёвеншёльд» - ориентируется на фольклорную традицию свадебной обрядности. Страстность натуры и заносчивость как родовые черты Лёвеншёльдов заставляют Шарлотту, влюбленную в Карла-Артура, бросив вызов судьбе, сказать, что, если бы к ней посватался самый богатый в округе заводчик Шагерстрём, она бы ему не отказала. И Шагерстрём действительно сватается к ней. С этого момента в силу вступает логика свадебного обряда (см.: [Брак у народов..., 1990: 43-45]), которая не вполне осознается самой героиней:

- сватовство Шагерстрёма,

- «величания» в адрес Шарлотты и Шагестрёма, которые произносит пастор Форсиус, опекун Шарлотты,

- визит пастора в поместье Шагерстрёма, соответствующий обрядовому элементу «смотрины дома жениха»,

- букет цветов от Шагерстрёма как аналог рукобития,

- оглашение в церкви как обязательный элемент подготовительного этапа свадьбы,

- затворничество и плач невесты,

- «кошачий концерт», который устраивают перед домом пастора молодые люди, возмущенные поведением Шарлотты, подозревая ее в корысти и вероломстве. Этот эпизод романа соответствует имеющему место в германском фольклоре обрядовому элементу: вечером перед первым оглашением парни поднимали стрельбу перед домом брачующихся, стучали кувшинами, крышками, горшками, чтобы отогнать злых духов [Брак у народов..., 1989: 17-18]. 
Особого внимания заслуживает описание состояния Шарлотты от сватовства до свадьбы (как говорит сама героиня, со «сватовства начались все беды»). В жизни Шарлотты происходят кардинальные перемены: расстраиваются ее отношения с Карлом-Артуром, она постоянно плачет, находясь в изоляции, поскольку все начинают ее избегать. Шарлотта принимает добровольное заточение - сидит в буфетной и режет старые тряпки для плетения ковриков, ни с кем не разговаривает, не оправдывается и не объясняет свои действия. Все эти события во второй части трилогии соответствуют универсальной структуре обряда перехода. Согласно А. К. Байбурину, в восточнославянской обрядовой традиции после сватовства появляются ограничения на передвижение невесты, ее «жизненное пространство» уменьшается, теперь невеста может передвигаться только с чьей-то помощью. Также невеста как бы отходит от повседневных дел, своего обычного образа жизни и поведения, лишается признаков живого человека: возможности ходить, активно действовать, говорить [Байбурин: 67]. «Погляди, на кого ты похожа! Краше в гроб кладут» (237); «Она ведь теперь пребывала в заоблачных высях, и всё, что происходило на земле, так мало в сущности, для нее значило» (161); «Шарлотта, которая в эти дни постоянно ощущала слабость и какую-то необъяснимую усталость, брела медленно, понурив голову» (239), - эти характеристики героини вполне соответствуют «переходному» состоянию невесты.

Описание дома пастора, где находится невеста до дня свадьбы, также включает в себя обрядовый траурный подтекст: старая усадьба имела «тревожный и неприветливый вид», гардины на окнах были опущены.

Кульминационным моментом в развитии мотива символической смерти невесты становится эпизод с публичным рассказом-исповедью Карла-Артура о его любви к Шарлотте, сделавшим ее предметом насмешек. Узнав об этом, героиня чувствует, что Карл-Артур «убил любовь», - «после этого и она должна была умереть» (279), и «она вдруг почувствовала такую пустоту!» (279).

Далее С. Лагерлёф воспроизводит следующие обрядовые элементы: 
- приезд жениха в дом невесты,

- венчание, которое могло происходить в церкви, в доме родителей невесты, а иногда и в доме священника ${ }^{3}$ (в романе оно происходит в доме пастора),

- прощание с родителями (опекунами),

- переход в дом жениха,

- свадебный пир и танцы с похищением невесты.

В романе описаны украшение дома и традиции, соблюдавшиеся на свадьбе у шведов: по пути, где должны проезжать молодые, были воздвигнуты цветочные арки, вдоль дороги вывешены флаги, поставлены пушки для салютов. Стрельба из пушек (ружий) является традиционным обычаем на шведской свадьбе (Е. Г. Кагаров в работе о свадебной обрядности толкует шум и стрельбу на свадебном празднике как апотропеические средства, защищающие от влияния сил «иного» мира [Кагаров: 152-195]).

Обретение нового статуса маркируется Шарлоттой ощущением, что «она попала в новый, счастливый мир» (289). Затем происходит осмотр имения жениха, нового дома и свадебный пир. Одним из обязательных элементов на шведской свадьбе являются танцы (см. об этом: [Rüütel: 391]). Танец молодой жены как ее первое публичное появление в новом доме - обычай, известный многим странам. Шарлотта сначала танцует с женихом, затем с другими мужчинами: кузнецами и мельниками, стариками и подростками. Похищение невесты - также довольно распространенный свадебный обычай (см.: [Кагаров: 169]). Однако в романе крадут не Шарлотту, а она сама, узнав о намерении Шагерстрёма уехать, крадет экипаж мужа.

С. Лагерлёф не стремится полностью реализовать структуру свадебного обряда. Писательница использует фольклорную традицию и вплетает ее в литературный текст, наполняя новым содержанием. С образом невесты как ключевой фигуры обряда связана главная мысль автора о животворящей силе любви и самопожертвования. Шарлотта Лёвеншёльд, выходя замуж за нелюбимого человека, жертвует собой ради КарлаАртура, принимая на себя всю вину за их размолвку и его безрассудство. Она становится изгнанницей в обществе, 
терпит клевету, не стремясь оправдаться. Героиня находит силы перенести даже презрение со стороны матери КарлаАртура - полковницы Беаты Экенстедт, горячо любимой Шарлоттой. Увидев нежную встречу и примирение матери с сыном, героиня понимает, что жертвует собой не напрасно. Кроме того, смысл жертвы для Шарлотты удваивается: теперь, будучи женой заводчика Шагерстрёма, она сможет помочь своей бедной умирающей сестре и ее детям.

По мысли С. Лагерлёф, путь смирения, добровольного страдания как индивидуального выбора возвышает человека, обогащает его духовно и помогает достичь нравственной высоты. В этом отношении показательны описания чувств самой Шарлотты: она ощущает нечто сродни трепету, возвышение над будничной суетой, тихую торжественность, нежное умиление и сострадательное сочувствие, ее переполняют восхищение и любовь от возможности «жертвовать собою ради счастья других» (162). Ту же возвышенную торжественность видит в Шарлотте Шагерстрём:

«Она выглядела так, точно прошла сквозь сильный огонь, который не обжег и не закоптил ее, а лишь выжег все наносное, все несовершенное, и она вышла из него еще светлее и чище» (174).

Любовь Шагерстрёма становится ее утешением и наградой.

Образ заводчика Шагерстрёма представляет собой вариант романтического героя. Это сильная, во многих отношениях исключительная личность: он очень остро ощущает свою внешнюю некрасивость, всего в своей жизни добивается сам, мучительно переживает смерть первой жены, а потом также страстно влюбляется в Шарлотту и мучится от осознания того, что девушка выходит за него по воле обстоятельств. Прозорливая Беата Экенстедт, мать Карла-Артура, называет главную черту Хенрика Шагерстрёма - «умение любить». Характерным является эпизод уже в третьей части трилогии, когда Беата Экенстедт говорит, что желала бы иметь такого сына, как Шагерстрём. В этот момент происходит внутреннее преображение героя: он перестает ощущать свое внешнее уродство и неуклюжесть, падает на колени и плачет от благодарности за эти слова. Для него, человека, не знавшего родительской ласки, прошедшего черед лишения и одиночество, добившегося всего своим 
упорным трудом, любовь является высшей ценностью, счастьем и наградой.

Вторая часть трилогии написана в традиции романтического романа первой половины XIX века. Автор неоднократно подчеркивает «романтичность» своих героев, их поступков и мыслей: «...в облике полковницы Беаты Экенстедт было что-то романтическое» (87), Карл-Артур «был более романтического склада, нежели его сестры» (89), Тея Сундлер «была романтиком с головы до ног» (136), наконец, Шагерстрёму, богачу и владельцу многих рудников и заводов, всегда была свойственна «склонность ко всему романтическому» (109). В сюжете романтического романа преображающая сила любви становится тем смыслом, который помогает героям преодолеть все испытания.

Эстетической концепции романтического героя соответствует и мотив вызова судьбе и ее власти над человеком, с которого начинается новый путь Шарлотты Лёвеншёльд. Шарлотту не оставляет мысль, что после сватовства она больше не властна в своих поступках, что «ее точно узницу ведут неизвестно куда» (229). Этот мотив тесно связан, как уже было сказано, с обрядовой традицией, но у С. Лагерлёф он получает психологическую трактовку. Мотив злого рока (пересекающийся с мотивом проклятого рода) воспринят опять же из фольклорно-мифологической традиции. Мотив судьбы можно назвать «мифологической универсалией, дающей в фольклорной традиции жизнь целому ряду международных сюжетов и образов, художественных реализаций различных сущностей понятия судьбы» [Ивашнева: 64]. Художественная реализация у С. Лагерлёф предполагает, как всегда, двойственный план прочтения: действие злого рока, довлеющего над Лёвеншёльдами, постоянно интуитивно ощущается героями, но одновременно с этим каждый из них сознательно совершает личный психологически мотивированный выбор. Показателен эпизод, когда Шарлотта догадывается о том, что у нее есть соперница, старающаяся разлучить их с Карлом-Артуром:

«Разумеется, она любит его. И как же это я раньше не догадалась! Этим все и объясняется. Оттого-то она и разлучила нас”. <...> ...можно было ожидать, что открытие, сделанное Шарлоттой, 
опечалит или испугает ее, но этого не произошло. Напротив, она подняла голову, ее поникшие плечи распрямились, и в осанке ее снова появились обычная гордость и независимость. $<\ldots>$ - А я-то думала, что это злосчастный перстень снова навлекает на нас беду! — бормотала она про себя» (240).

Однако родовые черты характера Лёвеншёльдов не позволяют героям найти путь к примирению, и Шарлотта должна выйти замуж за Шагерстрёма, которого пока не любит и, по существу, совсем еще не знает.

В третьей части трилогии - «Анна Сверд» - С. Лагерлёф обращается к реалистическому изображению действительности. Из текста полностью уходит характеристика «романтический», несмотря на то, что действующие лица остаются в большинстве своем те же. Изображение усадебной дворянской жизни сменяется картинами крестьянского быта, тяжелого труда далекарлийских коробейниц, бедности, несчастной жизни детей-сирот, которых продают на аукционе и отправляют побираться по деревне, крестьянских обрядовых праздников, ярмарок и т. д.

При этом повествование в третьей части воспроизводит сказочные сюжетные модели. «Волшебное» знакомство героев происходит еще во второй части трилогии: Карл-Артур после очередной ссоры с Шарлоттой решает посвататься к первой встречной. На его пути как возможные варианты оказываются несколько «невест»: нищенка, богачка, две распутницы (скотница и дочка содержателя постоялого двора), но все они «сходят с дороги». И наконец появляется та, на которой герою суждено жениться, - красавица Анна Сверд.

При встрече Шарлотты Лёвеншёльд с Карлом-Артуром в третьей части трилогии, ей на ум приходит сравнение его со сказочным принцем:

«Теперь он стоял всего в нескольких шагах от Шарлотты, и она видела, что он очень бледен, но что кожа на его лице все такая же нежная, мальчишеская. Он, пожалуй, немного постарел, черты лица стали резче, но та утонченность, которая отмечала лицо сына полковницы Экенстедт, не исчезла. Шарлотта нашла, что он в своей серой одежде из сермяги был похож на современного Пера Свинопаса, переодетого принца» (440). 
Подобно героине волшебной сказки о мудрой деве [Мелетинский, 2005: 44-45, 99-108], Анне Сверд, бедной крестьянке, коробейнице с Севера, выпало счастье выйти замуж за принца. Мотив «чудесной женитьбы» реализуется в неоднократно повторяющихся формулах, которые произносит Анна Сверд: «Чудо со мной приключилось превеликое. О таких чудесах только в Библии писано. В пору в церкви про такое проповеди сказывать» (325), «За пастора выхожу и жить стану в пасторской усадьбе. У меня будут лошадь и корова, служанка и работник» (321). Так, троекратные повторы, характерные для сказки, использует и С. Лагерлёф.

Вариант сказочного испытания мудрой девы представляет собой эпизод обучения героини. В сказке элементы ритуализированных форм проверки трудовых навыков невесты-крестьянки, переходящей в семью мужа в качестве работницы, преобразуются в форму загадки [Мелетинский, 2005: 152]. Анна Сверд также разгадывает загадку. Ленсманша (жена полицейского), от которой зависело разрешение на брак, ставит условие для неграмотной девушки:

«-<..> Здесь написано: Карл-Артур. Попробуй написать это имя. Коли ты его любишь, так непременно напишешь.

И она вложила перо в руку Анне» (337).

Через час, как пишет С. Лагерлёф, «они увидели чудо»: не умея писать, Анна вышила имя возлюбленного.

Второе испытание невесты - обучение манерам и этикету в доме ленсманши, а третье (уже после замужества) - работа за ткацким станком в доме пастора. Оценив мастерство и характер Анны, пасторша произносит:

«Теперь-то уж я твердо знаю, что ты нашел именно такую жену, какая тебе нужна» (392).

Однако если счастливый брак должен стать последним пунктом или развязкой сказки [Мелетинский, 2005: 44], то в «Анне Сверд» надежды героини на счастливый брак рушатся - все беды и трудности начинаются именно после свадьбы. В третьей части трилогии происходит трансформация канонов сказочного сюжета и любовно-романтического повествования 
в социально-психологическое осмысление жизни, характерное для реалистического романа.

Дальнейшее повествование развивает сказочный мотив противостояния истинного и ложного героя (см. об этом: [Пропп: 56-58]). В качестве главного антагониста Анны Сверд выступает Тея Сундлер, расстроившая свадьбу Карла-Артура с Шарлоттой Лёвеншёльд, а теперь стремящаяся разрушить его брак с Анной. Две героини - ложная и истинная - представляются двумя противоположностями, причем и в этом противостоянии Анне приходится проявлять мудрость и смекалку. Анна Сверд, сочетая в своем характере черты подлинной «дочери народа» («писательнице кажется, что в этой простой крестьянской девушке запечатлены черты прекрасных и величественных женщин прошлого») [Брауде: 18]: умение трудиться, выживать в тяжелых условиях, быть хорошей женой и хозяйкой, доброй и ласковой матерью, одновременно она может быть мужиковатой, грубой. В простой крестьянке Карл-Артур видит, будто «какая-то колдовская сила дала ей в наследство достоинство владелиц древних замков. То, что другие находили грубым в ее манерах и поведении, сохранилось на самом деле от старинных обычаев тех времен, когда королевы разводили огонь в очаге, а принцессы ходили на реку полоскать белье» (384).

Образ Теи Сундлер - самый загадочный и противоречивый из всех женских персонажей в трилогии. Она - дочь Мальвины Спаак, женщины, вернувшей перстень в могилу генералу Лёвеншёльду. На первый взгляд, Тея предстает человеком несчастной судьбы: с детства «неуклюжая коротышка с глазами навыкате, да к тому же еще и шепелявила» (518). Она бедна и некрасива, несчастна в браке и, кроме того, безнадежно влюблена в молодого Карла-Артура. Однако женщина умна и коварна, умеет вселить сомнения в душу собеседника. Она делает все, чтобы быть с человеком, которого любит, одновременно губя его самого.

В образе Теи Сундлер можно обнаружить большое количество черт, присущих мифологическим и фольклорным персонажам (о типологических чертах низшей мифологии см.: [Виноградова]). Так, главными достоинствами и гордостью 
Теи Сундлер являются прекрасные локоны и красивый чистый голос, что роднит ее с водными женскими демонологическими существами. Другие героини дают ей такие характеристики: «...мерзавка до такой степени гнусна, что отравляет воздух, которым дышит; она, верно, сеет рознь всюду, где бы ни появлялась, и речи ее жалят, точно змеиный укус» (154), «она малость с придурью. <...> Ее здесь никто не любит» (160), «Ах ты жаба!» (190), «толстуха Сундлер с ее рыбьими глазами» (241), «змея подколодная, каждодневно источающая яд на его $<$ Карла-Артура> раны» (508), «ее самое слишком часто в грязь окунали. Ей уже теперь не отмыться» (386). Характерен «победный марш» Теи Сундлер после ухода Анны Сверд из дома:

«По полу ползала женщина: она собирала маленькие упрямые карточные снежинки <...>. Она мурлыкала песню и, казалось, была в наилучшем расположении духа. Когда он вошел, она подняла голову, и он увидел, что это была Тея. <...>

- Что с тобой, Тея, в своем ли ты уме?

В голосе его звучало презрение и, пожалуй, даже ненависть. Тея подняла глаза и увидела, что лоб его нахмурен, но она только рассмеялась.

— Да, - сказала она, - это тебе удается с другими, но не со мной. Бей меня, пинай! Я все равно вернусь. От меня тебе никогда не отделаться. То, что пугает других, меня привязывает еще крепче» (446).

Мотивы общественной изоляции, нечистых животных, низового положения, а также магической силы слов и желаний связывают образ Теи с фольклорными образами демонологических существ [Виноградова: 17-25].

Речи Теи опутывают, зачаровывают, сбивают с толку. Их влияние испытывает на себе и Анна Сверд, которая после разговора с фру Сундлер вспоминает, что существуют поверья о злых троллях, которые завораживают людей, и им видится то, чего нет на самом деле. Даже здравомыслящая Шарлотта Лёвеншёльд начинает чувствовать, что на стороне Теи стоит нечто грозное и неотвратимое. Когда Тея, разлучив КарлаАртура с женой, становится его помощницей в проповедях на ярмарках, происходят метаморфозы и с ее прекрасным голосом: «...голос отнюдь не был красив, но песнь неслась 
с такой силой, что прямо-таки оглушала» (505), — тем самым раскрывается ее демоническая, чудовищная сущность. Никто не властен помешать влиянию Теи на Карла-Артура, и он сам не в силах избавиться от нее: «Я сам испробовал все возможное. Но спасения нет. Нет спасения, кроме смерти» (533).

Тея Сундлер, дочь Мальвины Спаак, выступает орудием мести Марит Эриксдоттер роду Лёвеншёльдов. Мотив мести характерен для исландских саг и эддической поэзии, причем самая действенная месть заключалась не в убийстве обидчика, а того, чья смерть нанесет сильнейший удар обидчику (см. об этом: [Стеблин-Каменский, 1984: 82-90]). В «исландских сагах», осуществляя месть, человек долго выжидал удобного случая для отмщения, что могло занимать не один год. Убийство из мести осуществлялось вне зависимости от чувств обиженного - согласно морали, характерной для «саг об исландцах», смерть героя не могла остаться неотомщенной [Стеблин-Каменский, 1979: 160]. Все это соответствует мотиву мести в трилогии, где за трех невинных крестьян должны были умереть трое из рода Лёвеншёльдов: гибнут два сына Адриана Лёвеншёльда и приемная дочь Шарлотты. При этом двое из них погибают по вине Теи Сундлер и Карла-Артура, пытавшихся украсть девочку.

Несмотря на это, противостояние героев с Теей Сундлер прочитывается в трилогии как их путь к спасению и духовному преображению. Идея преображения является одной из ключевых в христианской культуре, и именно она составляет внутренний сюжет романов С. Лагерлёф. Особенно показательной в этом смысле является история Карла-Артура Экенстедта.

С. Лагерлёф описывает путь пастора, который не умеет любить. Все его усилия явить миру Благую весть не увенчались успехом, потому что сам он - «медь звенящая или кимвал звучащий», который говорит языками человеческими и ангельскими, а любви не имеет (1 Кор. 13:1). Несмотря на то, что многими поступками героя руководят благородные мотивы, их последствия причиняют боль любящим его людям. Один из ярких эпизодов романа «Шарлотта Лёвеншёльд» - аукцион, где Карл-Артур забирает на свое попечение десять бедных сирот, но далее 
тяготится своим решением: дети становятся для него обузой, преградой на пути к счастью с женой. По совету Теи Сундлер, он без угрызений совести отдает детей их дальнему родственнику, хотя и Анна Сверд, и сами дети стали от этого решения несчастными. Именно в образе Карла-Артура раскрывается проблема нравственного падения человека. Герой, напоминавший когда-то переодетого принца, превращается в «чудовище», ненавидящее всех и вся, и более того - становится причиной смерти двух невинных людей и неизлечимой болезни своей матери.

В шведской критике философская концепция произведений Лагерлёф характеризуется троичной структурой: заблуждение, осознание, примирение (см. об этом: [Кобленкова, 2017: 313-323]). Противоречивый и непростой жизненный путь Карла-Артура отражает сюжетную структуру притчи о блудном сыне. Не случайно сам герой использует притчевую метафору, сочиняя для себя посмертное слово:

«Здесь, мол, покоится богатый юноша, который, повинуясь заповедям Христовым, расточил все свои имения и стал нищим...» (531).

Как и блудный сын, Карл-Артур сам отказывается от данного ему свыше, - от любви, которой его окружают мать, Шарлотта, Анна Сверд. Следуя своей гордыне, он растрачивает все таланты, которыми была одарена его натура. Желая жить согласно Божьим заповедям, в нищете, презирая земные блага, помогая ближним, своими прекрасными проповедями наставляя людей, Карл-Артур раздираем противоречиями. Именно этот образ, как и герой рассказа С. Лагерлёф «Изгои» Турд, становится воплощением конфликта между «идеей и натурой» [Сухих, 2014: 312]. Карл-Артур одержим своей идей, но когда дело доходит до ее практической реализации, герой оказывается не в состоянии справиться с этим. Отец Карла-Артура, обвиняя сына, говорит, что Бог, которому тот служит, - жестокий Бог. То есть даже неукоснительное следование Божьему закону, но без любви, сострадания и милосердия, не является, по мысли С. Лагерлёф, истинным христианским путем. 
Примирение героя с миром, с семьей, с женой наступает, только когда Карл-Артур, благодаря помощи Шарлотты, всетаки освобождается от Теи Сундлер и отправляется в Африку в качестве миссионера, где проводит несколько лет. Он наконецто обретает свое место в жизни и научается любить ближнего, ведь «тот, кто, не любя ближнего, желает следовать Христу, тот непременно ввергает в беду и самого себя и других» (537). Возвращением к жене и обретением своего дома, окончанием поисков и метаний завершается история Карла-Артура.

Как уже отмечено нами ранее, в трилогии очень тонка граница между реальным и мистическим мирами. Общий принцип перехода от одного к другому определен тем, что герои представлены как психологические персонажи, наделенные «мифической маской». Как пишет Ларс Т. Нюландер (Lars T. Nylander), логика такого сочетания следует метафоре маскарада: люди играют или воплощают мифические фигуры, а их самые сокровенные «я», их истинные лица за масками, остаются психологическими (см. об этом: [Nylander: 419]). Благодаря двойственной трактовке действий и мотивов персонажей, с помощью символов, пересечений сюжетных линий, С. Лагерлёф дает возможность различного истолкования одного и того же события. То, что считалось сверхъестественным явлением, может быть истолковано как совпадение, предчувствие, иллюзия, видение, чувство страха (см. об этом: [Setterwall: 124]). Вместе с тем в самом сверхъестественном дискурсе сталкиваются демоническая мистика и христианская вера в божественные законы добра и любви.

В этой логике представлен и путь Карла-Артура. Смерть барона Лёвеншёльда и его племянницы, приемной дочери Шарлотты Лёвеншёльд, можно расценить как сбывшееся проклятье, морок, наводимый Теей Сундлер, но и как несчастный случай, ставший одновременно крайней точкой нравственного падения Карла-Артура, психологическое напряжение которой подвигло его, наконец, на путь преображения. Как отметила О. С. Сухих, у Лагерлёф «духовное возрождение человека связано с его приближением к христианской этике, в которой ключевым понятием является любовь к ближнему» 
[Сухих, 2016: 242]. С. Лагерлёф особенно дорога мысль о том, что не злой рок заставляет страдать ее героев, а Бог направляет их к лучшему:

«Точно затравленного зверя, гнал его Господь Бог в западню, все пути были ему заказаны, кроме этого - единственного. А потом оказалось, что путь этот и был истинный, тот, который ему следовало бы избрать с самого первого дня» (537).

Все герои трилогии С. Лагерлёф проходят свой путь через страдание к обретению счастья, жизненные трудности нравственно преображают героев, в их чертах появляется благородство, достоинство, мудрость, умиротворение, спокойствие или кротость. Оставляя возможность двойственного прочтения текста, бережно и с уважением обращаясь с традиционным крестьянским фольклором, С. Лагерлёф оценивает своих героев с высоты христианской идеи, выражающей сущность ее авторского «я».

\section{Примечания}

1 Нобелевская премия по литературе (1909). Сельма Лагерлёф. [Электронный ресурс] // Лауреаты Нобелевской премии. URL: http://www. nobeliat.ru/laureat.php?id=10 (12.06.2018).

2 Лагерлёф С. Перстень Лёвеншёльдов. Шарлотта Лёвеншёльд. Анна Сверд. Романы / пер. со швед. Л. Брауде, Н. Беляковой, Ф. Золоторевской; примеч. Ф. Золоторевской, Н. Беляковой. М.: Панорама, 1993. С. 15. Здесь и далее ссылки на это издание приводятся в тексте статьи с указанием страницы в круглых скобках.

3 О традиции венчания у шведов и норвежцев, которое могло происходить в церкви, в доме родителей невесты, а иногда и в доме священника, см., напр.: [Водовозова: 110]. 


\section{Список литературы}

1. Байбурин А. К. Ритуал в традиционной культуре. Структурно-семантический анализ восточнославянских обрядов / А. К. Байбурин; РАН, Музей антропол. и этнограф. им. Петра Великого (Кунсткамера). СПб.: Наука, 1993. - 240 с.

2. Брак у народов Западной и Южной Европы / Ю. В. Иванова [и др.]; отв. ред. Ю. В. Иванова и др.; АН СССР, Ин-т этнографии им. Н. Н. Миклухо-Маклая. - М.: Наука, 1989. - 242 с.

3. Брак у народов Северной и Северо-Западной Европы / Г. И. Анохин [и др]; отв. ред. Ю. В. Иванова; АН СССР, Ин-т этнографии им. Н. Н. Миклухо-Маклая. - М.: Наука, 1990. - 173 с.

4. Брауде Л. Ю. Сельма Лагерлёф и ее трилогия Лёвеншёльдах // Лагерлёф С. Перстень Лёвеншёльдов. Шарлотта Лёвеншёльд. Анна Сверд. Романы. - М.: Панорама, 1993. - С. 5-20.

5. Виноградова Л. Н. Славянская народная демонология: проблема сравнительного изучения: дис. ... д-ра филол. наук: 10.01.09. - Москва, 2001. - $92 \mathrm{c}$.

6. Водовозова Е. Н. Как люди на белом свете живут. Шведы и норвежцы. - СПб.: Тип. М. М. Стасюлевича, 1901. - Т. 4. - 177 с.

7. Гаричева Е. А. Феномен преображения в русской художественной словесности XVI-XX веков: дис. ... д-ра филол. наук: 10.01.01. - Москва, 2009. $-456 \mathrm{c}$.

8. Гуревич А. Я. «Эдда» и сага. - М.: Наука, 1979. - 192 с.

9. Гуревич А. Я. Категории средневековой культуры. - 2-е изд., испр. и доп. - М.: Искусство, 1984. - 350 с.

10. Ивашнева Л. Л. Мотив предопределения судьбы персонажа в фольклорной прозе // Русская литература. - 2013. - № 2. - С. 64-80.

11. Кагаров Е. Г. Состав и происхождение свадебной обрядности // Сборник Музея антропологии и этнографии. - Л.: Изд-во АН СССР, 1929. T. 8. - С. 152-195.

12. Кобленкова Д. В. Миф в шведской прозе ХХ века и проблема «нобелевского формата» // Вестник Нижегородского университета им. Н. И. Лобачевского. - 2012. - № 1 (2). - С. 100-105.

13. Кобленкова Д. В. Творчество С. Лагерлёф и традиции русской классической литературы (роман «Император Португальский») // Россия и Скандинавия: литературные взаимодействия на рубеже XIX-XXвв. / сост. и отв. ред. Е. А. Тахо-Годи. - М.: ИМЛИ РАН, 2017. - С. 313-322.

14. Криничная Н. А. Историко-этнографическая основа преданий о «зачарованных кладах» (по материалам русских северных преданий) // Советская этнография. - 1977. - № 4. - С. 105-111.

15. Левкиевская Е. Е. Привидение, призрак // Славянские древности: этнолингвистический словарь: в 5 т. / под общ. ред. Н. И. Толстого. М.: Международные отношения, 2009. - Т. 4. П (Переправа через воду) - С (Сито). - С. 263-265.

16. Лосев А. Ф. Мифология греков и римлян / А. Ф. Лосев; сост. А. А. Тахо-Годи; общ. ред. А. А. Тахо-Годи и И. И. Маханькова. - М.: Мысль, 
1996. - 975 с.

17. Мелетинский Е. М. Скандинавская эпическая поэзия // История всемирной литературы: в 8 т. / АН СССР; Ин-т мировой лит. им. А. М. Горького. - М.: Наука, 1984. - Т. 2. - С. 467-476.

18. Мелетинский Е. М. Герой волшебной сказки. - М.; СПб.: Академия Исследований Культуры, Традиция, 2005. - 240 с.

19. Мелетинский Е. М. Вальхалла // Мифы народов мира. Онлайн энциклопедия / гл. ред. С. А. Токарев. [Электронный ресурc]. - URL: http:// www.mifinarodov.com/v/valhalla.html (12.06.2018).

20. Напцок Б. Р. Английский «готический» роман: к вопросу об истории и поэтике жанра // Вестник Адыгейского государственного университета. Серия 2: Филология и искусствоведение. - 2008. — № 10. - С. 139-144.

21. Плахтиенко О. П. Детство как источник творчества (автобиографический роман Сельмы Лагерлёф «Морбакка») // Педагогический дискурс в литературе: материалы XI Всероссийской научно-методической конференции. - СПб., 2017. - С. 26-30.

22. Померанцева Э. В. Мифологические персонажи в русском фольклоре. - М.: Наука, 1975. - 192 с.

23. Пропп В. Я. Морфология сказки. - Л.: Academia, 1928. - 152 с.

24. Соколова В. К. Русские исторические предания. - М.: Наука, 1970. $288 \mathrm{c}$.

25. Стеблин-Каменский М. И. «Саги об исландцах» и «Сага о Греттире» // Стеблин-Каменский М. И. Сага о Гретире. - Новосибирск: Наука, 1976. - С. 149-161.

26. Стеблин-Каменский М. И. Древнескандинавская литература. - М.: Высшая школа, 1979. - 192 с.

27. Стеблин-Каменский М. И. Мир саги. Становление литературы. - Л.: Наука, 1984. - 245 с.

28. Сухих О. С. Преступление и наказание в рассказе С. Лагерлёф «Изгои» // Вестник Нижегородского университета им. Н. И. Лобачевского. - 2014. — № 2 (2). - С. 311-316.

29. Сухих О. С. Путь «от смерти к жизни» («Преступление и наказание» Ф. М. Достоевского и «Отлученный» С. Лагерлёф) // Вестник Нижегородского университета им. Н. И. Лобачевского. - 2016. - № 4. С. 239-246.

30. Толстой Н. И. Граница // Славянские древности: этнолингвистический словарь: в 5 т. / под общ. ред. Н. И. Толстого. - М.: Международные отношения, 1995. - Т. 1. А (Август)-Г (Гусь). - С. 537-540.

31. Хализев В. Е. Теория литературы. - М.: Высшая школа, 2004. - 405 с.

32. Элиаде М. Священное и мирское / пер. с фр., предисл. и коммент. Н. К. Гарбовского. - М.: Изд-во МГУ, 1994. - 144 с.

33. Danielson L. W. The Uses of Demonic Folk Tradition in Selma Lagerlöf's "Gösta Berlings saga" // Western Folklore. — 1975. — Vol. 34. — № 3. Pp. 187-199. 
34. Landquist J. Selma Lagerlöf // Svensk litteraturtidskrift. — 1940. — Årg. 3. — S. $49-71$.

35. Nylander L. T. Psychologism and the Novel: The Case of Selma Lagerlöf's "Gösta Berlings saga" // Scandinavian Studies. — 1995. — Vol. 67. — № 4. — Pp. 407-433.

36. Rüütel I. Wedding traditions of the isle of Kihnu — roots and developments // Folk Belief Today. - Tartu, 1995. - Pp. 377-405.

37. Setterwall M. Two sides of an ending in "Herr Arnes penningar" // Scandinavian Studies. — 1983. - Vol. 55. — № 2. - Pp. 123-133.

Информация об авторах: Бедина Наталья Николаевна - кандидат филологических наук, доцент кафедры культурологии и религиоведения Северного (Арктического) федерального университета имени М. В. Ломоносова; Ившина Ольга Сергеевна - магистр по направлению «Филология» Северного (Арктического) федерального университета имени М. В. Ломоносова.

Дата поступления в редакиию: 04.07.2018

Дата публикации: 01.10.2018

Natalya N. Bedina

(Arkhangelsk, Russian Federation)

bedina-nat@yandex.ru

Ol'ga S. Ivshina

(Arkhangelsk, Russian Federation)

olgaivs1994@mail.ru

\title{
The Myphopoetic and Christian Motifs in The Ring of the Löwenskölds Trilogy by Selma Lagerlöf
}

\begin{abstract}
The peculiarity of S. Lagerlöf's artistic concept is the coexistence of myth and literature, folklore and Christian tradition, fiction and reality, mysticism and psychology within one text. The research aims to use the motive analysis to trace the peculiarities of the interrelation between folklore and Christian tradition in The Ring of the Löwenskölds trilogy. The first part of the trilogy ("The Ring of the Löwenskölds") focuses on the folklore demonological story and at the same time the Gothic novel of the late 18th century; the second part ("Charlotte Löwenskölds") corresponds to the wedding ritual tradition and at the same time implements the genre and stylistic features of the romantic psychological novel of the first half of the 19th century; the third part ("Anna
\end{abstract}


Svärd") transforms the folklore fairy tale tradition into a literary neoromantic novel of the second half of the 19th and beginning of the 20th century, taking into account the realistic literary experience. S. Lagerlöf leads her reader through the history of Swedish (and even wider - European) culture and along the way of the Christian Transformation, from the subjugation by the passions in the first part through self-sacrifice and love in the second part to acceptance of the world and humility in the third part.

Keywords: Neo-Romanticism, The Ring of the Löwenskölds, Lowenskoldska ringen, trilogy, folk motifs, Christian idea, spiritual transformation

\section{References}

1. Bayburin A. K. Ritual v traditsionnoy kul'ture. Strukturno-semanticheskiy analiz vostochnoslavyanskikh obryadov [The Ritual in the Traditional Culture. Structural and Semantic Analysis of East Slavic Rites]. St. Petersburg, Nauka Publ., 1993. 240 p. (In Russ.)

2. Brak u narodov Zapadnoy $i$ Yuzhnoy Evropy [The Marriage of the Peoples of Western and Southern Europe]. Moscow, Nauka Publ., 1989. 242 p. (In Russ.)

3. Brak u narodov Severnoy i Severo-Zapadnoy Evropy [The Marriage of the Peoples of Northern and North-Western Europe]. Moscow, Nauka Publ., 1990. 173 p. (In Russ.)

4. Braude L. Yu. Selma Lagerlöf and Her The Ring of the Löwenskölds trilogy. In: Lagerlyof S. Persten' Lyovenshyol'dov. Sharlotta Lyovenshyol'd. Anna Sverd. Romany [Lagerlöf S. The Ring of the Löwenskölds. Charlotte Löwenskölds. Anna Svärd. Novels]. Moscow, Panorama Publ., 1993, pp. 5-20. (In Russ.)

5. Vinogradova L. N. Slavyanskaya narodnaya demonologiya: problema sravnitel'nogo izucheniya: dis. ... d-ra filol. nauk [Slavic Folk Demonology: The Problem of a Comparative Study. PhD. philol. sci. diss.]. Moscow, 2001. 92 p. (In Russ.)

6. Vodovozova E. N. Kak lyudi na belom svete zhivut. Shvedy i norvezhtsy [How People Live in the World. Swedes and Norwegians]. St. Petersburg, Tipografiya M. M. Stasyulevicha Publ., 1901, vol. 4. 177 p. (In Russ.)

7. Garicheva E. A. Fenomen preobrazheniya v russkoy khudozhestvennoy slovesnosti XVI-XX vekov: dis. ... d-ra filol. nauk [The Transformation Phenomenon in the Russian Literature of the 16th and 20th Centuries. PhD. philol. sci. diss.]. Moscow, 2009. 456 p. (In Russ.)

8. Gurevich A. Ya. «Edda» i saga. Moscow, Nauka Publ., 1979. 192 p. (In Russ.)

9. Gurevich A. Ya. Kategorii srednevekovoy kul'tury [The Categories of the Medieval Culture]. Moscow, Iskusstvo Publ., 1984. 350 p. (In Russ.)

10. Ivashneva L. L. The Motif of Predestination of the Character's Fate in Folk Prose. In: Russkaya literatura, 2013, no. 2, pp. 64-80. (In Russ.)

11. Kagarov E. G. The Composition and Origin of Wedding Rituals. In: Sbornik Muzeya antropologii i etnografii [The Anthropology and Ethnography Museum Collection]. Leningrad, Academy of Sciences of the USSR Publ., 1929, vol. 8, pp. 152-195. (In Russ.)

12. Koblenkova D. V. Myth in the Swedish Prose of the 20th Century and the 
Problem of the Nobel Format. In: Vestnik Nizhegorodskogo universiteta im. N. I. Lobachevskogo [Vestnik of Lobachevsky University of Nizhni Novgorod], 2012, no. 1 (2), pp. 100-105. (In Russ.)

13. Koblenkova D. V. The Works by S. Lagerlöf and the Traditions of Russian Classical Literature (the Novel "The Emperor of Portugalia"). In: Rossiya $i$ andinaviya: literaturnye vzaimodeystviya na rubezhe XIX-XX vv. [Russia and Scandinavia: Literary Interactions in the 19th and 20th Centuries]. Moscow, A. M. Gorky Institute of World Literature of the Russian Academy of Sciences Publ., 2017, pp. 313-322. (In Russ.)

14. Krinichnaya N. A. The Historical and Ethnographic Basis of the Legends About the "Enchanted Treasures" (Based on the Materials of the Russian Northern Legends). In: Sovetskaya etnografiya [Soviet Ethnography], 1977, no. 4, pp. 105-111. (In Russ.)

15. Levkievskaya E. E. Ghost, Phantom. In: Slavyanskie drevnosti: etnolingvisticheskiy slovar': $v 5$ tomakh [Slavic Antiquities: Ethnolinguistic Dictionary: in 5 Vols]. Moscow, Mezhdunarodnye otnosheniya Publ., 2009, vol. 4, pp. 263-265. (In Russ.)

16. Losev A. F. Mifologiya grekov $i$ rimlyan [The Mythology of the Greeks and Romans]. Moscow, Mysl' Publ., 1996. 975 p. (In Russ.)

17. Meletinskiy E. M. Scandinavian Epic Poetry. In: Istoriya vsemirnoy literatury: $v 8$ tomakh [History of World Literature: in 8 Vols]. Moscow, Nauka Publ., 1984, vol. 2, pp. 467-476. (In Russ.)

18. Meletinskiy E. M. Geroy volshebnoy skazki [The Hero of the Fairy Tale]. Moscow, St. Petersburg, Akademiya Issledovaniy Kul'tury Publ., Traditsiya Publ., 2005. 240 p. (In Russ.)

19. Meletinskiy E. M. Valhalla. In: Mify narodov mira. Onlayn entsiklopediya [Myths of the World. Online Encyclopedia]. Available at: http://www.mifinarodov. com/v/valhalla.html (accessed on June 12, 2018). (In Russ.)

20. Naptsok B. R. An English "Gothic" Novel: More on the History and Poetics of the Genre. In: Vestnik Adygeyskogo gosudarstvennogo universiteta. Seriya 2: Filologiya $i$ iskusstvovedenie [The Bulletin of the Adyghe State University. Series 2: Philology and the Arts], 2008, no. 10, pp. 139-144. (In Russ.)

21. Plakhtienko O. P. Childhood as a Source of Creativity (Autobiographical Novel of Selma Lagerlöf "Morbakka"). In: Pedagogicheskiy diskurs v literature: materialy XI Vserossiyskoy nauchno-metodicheskoy konferentsii [Pedagogical Discourse in Literature. Materials of the 11th All-Russian Scientific and Methodological Conference]. St. Petersburg, 2017, pp. 26-30. (In Russ.)

22. Pomerantseva E. V. Mifologicheskie personazhi v russkom fol'klore [Mythological Characters in Russian Folklore]. Moscow, Nauka Publ., 1975. 192 p. (In Russ.)

23. Propp V. Ya. Morfologiya skazki [The Morphology of the Fairy Tale]. Leningrad, Academia Publ., 1928. 152 p. (In Russ.)

24. Sokolova V. K. Russkie istoricheskie predaniya [Russian Historical Legends]. Moscow, Nauka Publ., 1970. 288 p. (In Russ.)

25. Steblin-Kamenskiy M. I. "The Sagas of Icelanders" and "Grettis Saga”. In: Steblin-Kamenskiy M. I. Saga o Gretire [Steblin-Kamensky M. I. Grettis Saga]. 
Novosibirsk, Nauka Publ., 1976, pp. 149-161. (In Russ.)

26. Steblin-Kamenskiy M. I. Drevneskandinavskaya literatura [Old Norse Literature]. Moscow, Vysshaya shkola Publ., 1979. 192 p. (In Russ.)

27. Steblin-Kamenskiy M. I. Mir sagi. Stanovlenie literatury [Saga's World. Formation of Literature]. Leningrad, Nauka Publ., 1984. 245 p. (In Russ.)

28. Sukhikh O. S. Crime and Punishment in the Novel "Outcast" by Selma Lagerlöf. In: Vestnik Nizhegorodskogo universiteta im. N. I. Lobachevskogo [Vestnik of Lobachevsky University of Nizhni Novgorod], 2014, no. 2 (2), pp. 311-316. (In Russ.)

29. Sukhikh O. S. The Way "from Death to Life" "Crime and Punishment" by Fedor Dostoevsky and "The Outcast" by Selma Lagerlöf). In: Vestnik Nizhegorodskogo universiteta im. N. I. Lobachevskogo [Vestnik of Lobachevsky University of Nizhni Novgorod], 2016, no. 4, pp. 239-246. (In Russ.)

30. Tolstoy N. I. The Border. In: Slavyanskie drevnosti: etnolingvisticheskiy slovar': $v 5$ tomakh [Slavic Antiquities: Ethnolinguistic Dictionary: in 5 Vols]. Moscow, Mezhdunarodnye otnosheniya Publ., 1995, vol. 1, pp. 537-540. (In Russ.)

31. Khalizev V. E. Teoriya literatury [The Theory of Literature]. Moscow, Vysshaya shkola Publ., 2004. 405 p. (In Russ.)

32. Eliade M. Svyashchennoe i mirskoe [The Sacred and the Secular]. Moscow, Moscow State University Publ., 1994. 144 p. (In Russ.)

33. Danielson L. W. The Uses of Demonic Folk Tradition in Selma Lagerlöf's "Gösta Berlings Saga". In: Western Folklore, 1975, vol. 34, no. 3, pp. 187-199. (In English)

34. Landquist J. Selma Lagerlöf. In: Svensk litteraturtidskrift, 1940, vol. 3, pp. 49-71. (In Swedish)

35. Nylander L. T. Psychologism and the Novel: The Case of Selma Lagerlöf's "Gösta Berlings Saga". In: Scandinavian Studies, 1995, vol. 67, no. 4, pp. 407-433. (In English)

36. Rüütel I. Wedding Traditions of the Isle of Kihnu - Roots and Developments. In: Folk Belief Today. Tartu, Estonian Academy of Sciences Publ., 1995, pp. 377-405. (In English)

37. Setterwall M. Two Sides of an Ending in "Herr Arnes Penningar". In: Scandinavian Studies, 1983, vol. 55, no. 2, pp. 123-133. (In English)

Information about the authors: Bedina Natalya N. - PhD in Philology, Associate Professor of the Department of Culturology and Religious Studies of Northern (Arctic) Federal University named after M. V. Lomonosov; Ivshina Olga S. - Master's Degree in Philology of Northern (Arctic) Federal University named after M. V. Lomonosov.

Received: July 4, 2018

Date of publication: October 1, 2018 